\title{
Thematic Review of the Royal Hunt on the Sassanid Silver Plates: Emphasizing the Roundabout of the King's Head
}

\author{
Marziyeh Basiri Zadeh', Faranak Kabiri², Abdurahman Adisaputera ${ }^{3}$, Muhammad \\ Ridwan $^{4}$ \\ ${ }^{1}$ Graduated of Master of Art in Islamic Art, Soureh University, Tehran, Iran \\ ${ }^{2}$ Art Department, Faculty Member in Shahrekord University, Shahr-e Kord, Iran \\ ${ }^{3}$ Faculty of Languages and Arts, Uniersitas Negeri Medan, Indonesia \\ ${ }^{4}$ Universitas Islam Negeri Sumatera Utara, Medan, Indonesia \\ sara.basiri@gmail.com,abas_750@yahoo.co.id,bukharyahmedal@gmail.com
}

\begin{abstract}
Metalworking is among the arts that have been considered for its unique features throughout history. Perhaps one of the most important reasons for using it a lot is its stamina and more durability than other materials. Another thing to consider about this is technology and the use of metals, which Iran has a valuable background in this regard. Lorestan bronze are a prominent example of this. One of the most important periods in the use of metals is the Sassanid era, during which the period of art also flourishes. Sassanid art can be considered an important part of Iran and even the world. This art period is a bridge between pre-Islamic and post-Islamic periods in Iran. During the Sassanid Empire in Iran, many silver dishes have been made in Iran, some of which has still been remained. Many of these containers are made of precious metals to symbolize strength and credibility. One of the most important drawings used in these containers is the picture of hunting and its role and related topics. Hunting in the pre-Islamic era was one of the best works and honors of the kings, because one more thing in Sassanid art is the attempt to show the holiness and authority of the kings of this era; which has been shown in the use of designs such as the roundabout of the king's head or magnifying the king's image. In this paper, by presenting examples of silver Plates that includes the role of hunting of kings, it has been tried to introduce and examine these cases.
\end{abstract}

Keywords

sassanid art; metalworking;

hunting scenes; silver plates; kingdom authority

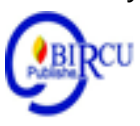

\section{Introduction}

The Sassanid dynasty in history (224-650 AD) was formed by Ardeshir, the founder of this dynasty of Sassan descendants of noble and Persian elders. After the death of the last king of Parthians, Ardeshir crowned himself in Tisfoon in 224 AD. The Sassanid dynasty, after the Parthians until the entrance of Islam to Iran, was one of the most influential Iranian dynasties, which have had a great influence in Iranian culture over the course of four centuries. "In the Sassanid era, which was the main sponsor of tradition and culture in the sense of an Eastern and Iranian government, symbolic effects and mysterious artistic works have been very interesting due to the diversity and richness of motifs. The visual arrays and entirely Iranian forms that the artists of the Sasanian era created were wonderfully impressive in other civilizations, and even in the later ages; and some have been imitated that examples 
of these motifs and silver plates are found in some of the monumental tracks of the time. The main theme of many of these works, both verbally and explicitly and symbolically and sequentially, is the continuation of the same tradition of honoring majestic majesty that uses it more precisely in religion and religious beliefs"'(Mobini, 1396, 61). In this paper, descriptive analyzes are attempted to find examples of the silver works in which the theme of the hunting was considered and examined, in order to introduce their features and provide an album of the image.

This present research answers following questions:

1. What are images of hunting scenes in Sassanid silver plates?

2. How does the Sassanid king appear in royal hunter in Sassanid silver plates?

3. How it could be explained, the composition of king's "far izadi "(divine glory) with the hunting scene in Sassanid plates?

4. Which kind of hunting tools and animals are shown in the Sassanid silver plates with presentation of king with far izadi (divine glory)?

\subsection{Background of Research}

In the field of works with Sassanid metal plates, many books have been written and research has been done; and the subject of hunting has also been addressed separately. For example: The book "Silver Sassanid plates" written by Mrs. Prendence Harper, an American researcher, or Arthur Pope, has also reviewed some Sassanid plates in viewing the Art of Iran, which analyzes some of the plates in that era; there are also articles in this regard that can be found on the article by Ms. Elham Vosough Babaei and Mrs. Neda Akhavan in the field of hunting scenes on the plates of this period. But in the present research, the scenes of the hunts are discussed, on the plates the symbol of the oven and the sanctity of the Sassanid kings in them somehow is displayed. This research has been done by descriptive-analytic method.

Imam Faisal Pane in his article entitled "The Study of Indisch Architecture Development as an Effort in Preserving the Heritage of Colonial History in Medan" stated that Historical development cannot be separated from the development of architecture.

Muhammad (2019) in his article entitled "Social Status Shift and Collapse of Uleebalang in Aceh of 1900-1946" defined Since the Dutch could take control of Aceh, the position of the ulama began to shift, because the Dutch surrendered government affairs to ullebalang (hulubalang), while the ulama were only given the qadhi position (the judge who ruled the case.(36)

\section{Review of Literatures}

\subsection{Hunting Position in Iranian Culture a. Hunting}

The picture of hunting and predation is one of the oldest and most primitive images used by prehistoric humans, because at that time hunting was one of the main pillars of human survival. From the images on the walls of the caves it can be seen that the concern of early humans has been hunting and overcoming animals. After humans settled in, they learned how to cultivate agriculture and raise domestic animals, and this hunting was replaced by agriculture. Gradually, the role of hunting, from the aspect of necessity, becomes an aspect of the expression of the authority of the king and the presence of a divine power in his body. 
"The Sassanian believed that their kingdom was the providence of the Lord, and the divine aspect of the responsibility of the King was that the kingdom of God and the king was the successor to God on earth. The fact that this celestial force is in the presence of the King remains the result of his victory in hunting, and therefore the royal hunt has been a suitable subject for artists in various fields" (Pop, 1378, 67).

"As it was said, hunting in the pre-Islamic era was one of the most important honors of the king. The King should prove his power in his various ways, including hunting and archery, to continue his empire. The hunting of the Sassanian hangings had the same validity and value in Hakhamaneshian times, which meant that the main recreation of the King and Sassanian elders was hunting. In the course of this period, the hunting program was also provided in ahead. So that the Shah's hunting was very entertaining, and many of the elders of the Sassanid court were accompanying them.

Since the Sassanian were considered themselves to follow the Hakhamaneshian, "The hunt also had the same passion for them as it had for the Hakhamaneshian kings. Kings were examining themselves in hunting on the scene; the great glorifying hunt and worthy of the kingdom; this fondness for the Sassanid kings was to hunt in such a way that they also, according to the ancient tradition, built their nesting hangars with rivets around them. This royal campus was full of numerous animal hunts where the Shah was hunting during a ceremony with the presence of multitudes and dancers. The specimens of these ceremonies are well featured in the two prominent batons, namely, in the boson of hunts and hunting hog and deer by the Sasanian king" (Tajbakhsh, 1374, 37).

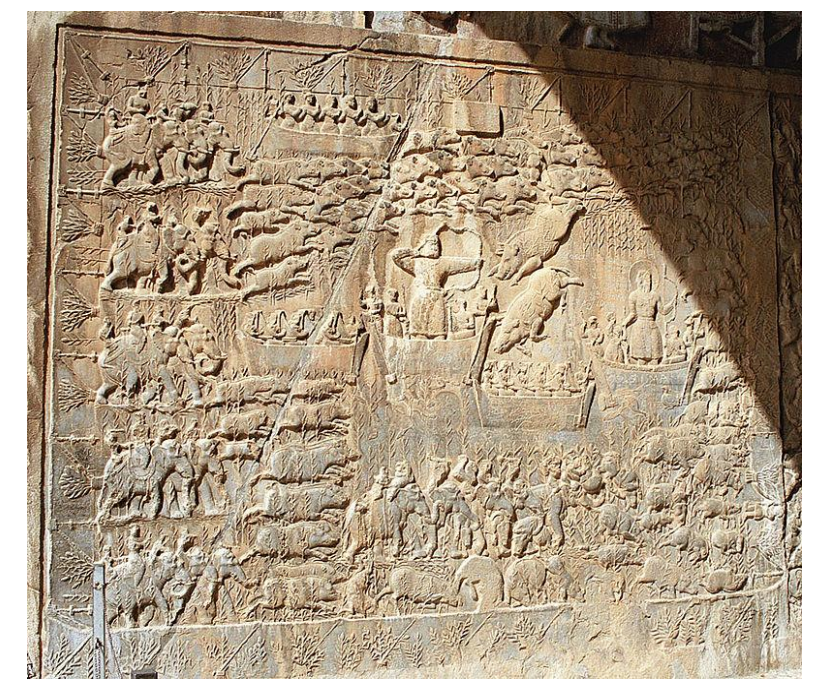

Figure 1. Prominent of Taq-e-Bostan, Hunting Hog, Wikipedia

Considering that the statistical society of this study is Sassanid silver plates, examples of them have been found by the role of hunter and hunting which the purpose of the production of these silverware was to use them during private life as well as ceremonies in the palace. These silver dishes reminded of the prosperity and economic prosperity, the consolidation of the political situation inside and outside, the comfort of the imagination and entertainment of the Sasanian kings and their conquerors.

"The royal hunting was a great hangman for a formal feast, and was not limited to one day or a week. The great ruler prepared himself for a month of hunting. Ten thousand riders, together with the Cheetah and Hawks, and a handful of hordes, went out of town. Of course, the pictures on plates do not really translate into the glamor of this recreational sport. But the 
best of such pictures were able to convey to the viewer merely the spirit of hunting and warfare by showing the king's personality and a few animals" (Akhavan, 1392, 38).

It should be noted that there is usually a connection between the shape of the plates and the pictures on them. For example, the subject of hunting on flat plates is evident. It is also seen in this container that only a few species of animals are hunted in the hunting scene and it does not have any traces of hunting birds. But it can be seen from hawk and eagle birds as hunting companions to share hunting animals.

\subsection{Silver Sassanian Plates}

The high quality of the plates indicates that they were produced by the order of the king in the palace or under the supervision of the King, and were sent as gifts for the reverence and showing the king's authority to other rulers.

"Not only did the Sassanid monarchs hand over trays and other silver containers to synonymous rulers, or in special circumstances, to their nobles and their com/.manding officers, but they were also sent to distant markets as a good and popular product. The construction of silver utensils was common in most workshops until it changed in Shapur II era (309-379); according to Prudential Harper, it was only when the production and use of silver became monopolized by the government. The bowls belonging to the middle period of the Sassanid kings are all similar in shape, weight and picture, and it is amazing that the chemical composition of their silver ore is the same. From then on, only the face of the Shah was stamped on plates."(ferrier,1374,70).

"At the time of Shapur II, he established special royal privileges and rights and imposed clear limits on princes and loyalties. This situation was changed. The silver plate with the scene of hunting was only assigned to the king, which is recognizable from the shape of his crown. With the decline in rock formations in Iran, there was an increase in the production of royal dishes. It was likely that the plates of the scene of hunting were made for the sake of sending gifts across the empire. They had found a form of royal propaganda. A political instrument similar to memorial medals, some silver dishes, and trophies in the west. These plates may have been distributed or produced during certain times during the reign of the Shah. One can follow the evolution of plates of the hunting scene during a long time, from the third to the 7th millennium. Expecting a lot of formal extras cannot be expected. These works are identical to the royal ideals, and there is only a modest change between the beginning and the end of this period".(ettinghausen,1379,115-119)

According to numerous studies on various dishes in this era, it became clear that the role of the main hunting has been done on plates. Since these designs are engraved on circular plates "In some cases, the circle is correctly understood as the circle's environment. As the circumference of the circle is often equated with a rotational motion. The circle or page is more of a sign of the sun, and a special relationship with the number 10 represents the return symbol of plurality to unity. Sometimes it means immortality"(cirlot,1388,384).

\subsection{Animals on the Scene of Hunting}

Given that in each scene of hunting, there is a hunter and an animal that is to be hunted, it is also necessary to examine the animals in this scene as a killing scene is in the Sassanid period.

\section{a. Hog}

The animal that is most commonly found on plates is hog. Hunting hogs from ancient times has become customary in all parts of the world, and the killing of hogs is usually a sign 
of courage. The hogs were hunted for using their meat as well as for preventing damaging the farms.

The hog in the mythology of the world has a special place. "The wild hogs have a long teeth and they are unlike tame pigs. In some European and Asian cultures, the hog is holy with magical power. In Vishnu's legend, hog in his role plays as the creator of the cosmos. They showed God in the form of a hunter and they were completely animal. The hog boot is a symbol of winter killing and unplugging for spring. In the art of Jesus, the hog represents the lust of seven sins" (Hall, 1380, 89).

"This animal is also very important in Iranian mythology. The hog in the Avesta, a sign and symbol of power and strength, is one of the manifestations of the god Bahram and victory. And his head is, in fact, an embodiment of the god of war, victory and war.

\section{b. Lion}

With regard to the available samples and the number of them, it can be argued that the lion is the second animal most hunted. "The finding of milk in ancient Iranian art shows that this animal once lived in that area"(Hall, 1380,61). The Lion, in principle, corresponds to the gold or the underground sun, as well as the sun, and therefore, in the ritual of communion, is the symbol of the Sun god.'(cirlot,1388,538)

\section{c. Ram or Goat}

"Each ancient tribe considered the mountain goat as one of the natural causes of the benefits. In the religious tradition, the people of Shoush had a special value and a sign of fertility and power. The symbol of the power of life and the creator of energy and symbolically lives in high places, and this is a sign of their greatness" (Porada, 1358, 42).

\section{d. Deer}

It is one of the animals that its picture appears in Pazizic rugs. "This animal was holy for the Indo-European and Central Asian peoples. In the Renaissance dialects, it was symbol of hearing, one of the five senses, and a symbol of caution of the main virtues. The deers are fast runners" (Hall, 1380, 91).

"The male deer due to the similarity of its horns with the foliage and leaves, its symbolic meaning is related to the tree. The male deer in many Asian cultures, because of the reminiscent of its branches and horn every time, is known as the symbol of rebirth".(cirlot,1388,662-663)

\section{e. Bear}

It can be considered as one of the native animals of Iran. "Bear is manifestation of force and courage and its image is used against robbers. In Christianity, it is the symbol of overeating, lust, and anger" (Hall, 1380, 45). "in the field of alchemy, the bear is equivalent to primitive materials of alchemy, and as a result, they are related to all the initial stages as well as instincts. They portray it as a cruel man'(cirlot,1388,364).

\section{f. Wolf}

It is among the animals which is found in the climate of Iran. "An animal that is mostly known as its bad reputation. A symbol of savage and cruelty. The wolf is seen on the flags of the Romans. Sometimes the wolf is the sign of Apollo" (Hall, 1380, 90). In the scenes of hunting on the silver plates, except in just one case, it has not been seen in other cases. "The wolf among the Romans and Egyptians is a symbol of valor. It also appears as a guard in many historical works".(cirlot,1388,650) 


\section{g. Horse}

The horse is present as a king seat in the hunting scene. "Horse in the myths and religious ceremonies of many civilizations has a great value, in the first place, he was a symbol of the sun and dragged his wheel and was sacrificed to the gods" (Hall, 1380, 25). In Avesta, it is reported that Zoroaster calls on Ahura Mazda to give him such a force, hearing, health and vision that he has given to the horse. Horse in Iran is a symbol of decency. The horse in Ancient Iran with the chariot is a sign of the god of wind, sun or sea. And in ancient India, the horse is a sign of the Sun goddess and goddess of the moon and the goddess of the wind, who are in common. (dadvar \& mansori,1385,265-266)

\section{h. Elephant}

The elephant is an animal which is seen in Iran's art. Among them are the prominent Taq-e-Bostan, many of which exist. But on hunting plates, there is only one case with the elephant's image that helps to hunt in the scene of hunting and collecting hunting. "Throughout the Orient, it has been shown as a religious symbol, the symbol of sovereignty, the sentimental wisdom, and the moral and psychological force. The elephant symbolized the royal privilege because only the kings had elephants" (Hall, 1380, 75). Among the important points of the image of Elephant in Iran was the authority and the main pillar of the Guards, and it was used in wars. In Iran, Elephant was considered to be an animal dependent on Ahriman".(dadvar\& mansori,1385,266).

\section{Discussion}

\subsection{Hunting Tools} is given.

One of the categories of hunts related to hunting is a tool for which a brief explanation

\section{a. Spear}

"It is the common weapons of warriors, predators, and gods of men and women. The Sanskrit word is the man's power and probably the similarity with the male organ. The spear is the symbol of war, as well as the symbol of the male organs" (Hall, 1380, 191). a weapon with a terrestrial and anti-sky concepts of the sword, a symbol of truth and righteous ness.(cirlot,1388,790-791).

\section{b. Bow and Arrow}

"The bow and arrow have a special place in Iranian culture and literature and have dedicated a lot of poems to itself. Pulling a string into a great arc was a test of bravery. The arc and the special feature of the gods of war and heroes are a very symbolic and sympathetic community for their indomitable bravery. The god of the Assyrian also had a bow and arrow" (Hall, 1380, 171). The bow is the sign of power of the goddess. The arrow and arrow associated with Apollo means the energy of the sun and its radius is cleansing and fertility. Arrow and beam shine the transcendental power. The arrow has also been a sign of the sun's rays.(cirlot,1388,243-630)

\section{c. The Sword}

"It consists of a blade and a knife, so it is counted as the symbol of unity. The sword has always been the exclusive right of the authorities(cirlot,1388,530-533). "The symbol of power, ability, justice, and sign of the gods, heroes and martyrs of Jesus is a weapon that was 
taken from the enemy. In the hands of the conqueror, he is considered a(n unassailable power. Therefore, receiving a sword at the coronation symbolically means that power is given to the king'(hall, 1380,1555).

\section{d. Winged Angel}

"The symbol of the invisible forces, the forces between the source of life and the universe, in the ups and downs of the symbolic reality of the angel, will not change the true reality, as in other cases, such as the cross. In alchemy, the angel is the symbol of sublimation"(cirlot,1388,589-590). "Human beings always sought for a relationship between themselves and the gods in which the angels played this role. They are propagation messengers who interconnected between gods and humans. Angels are comparable to Amasaspandan in the Zarathustra religion.'(hall,1380,260).

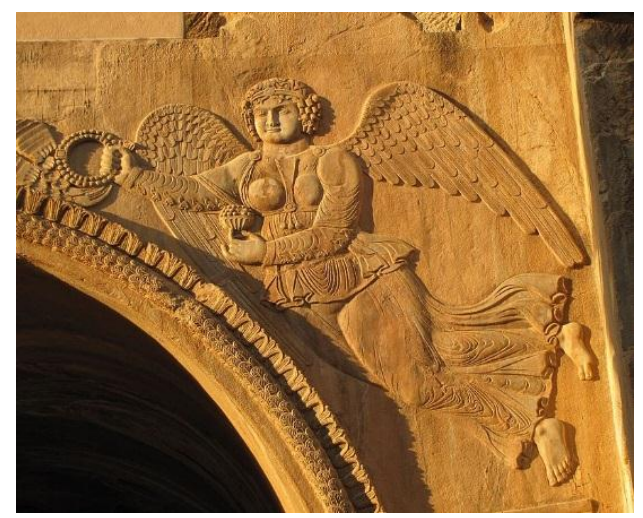

Figure 2. The Image of the Angel of Victory on the Top of the Tag-e-Bostan Wikipedia

The prominent coronation of Ardeshir II is seen in the Tag-e-Bostan as well as the hollo and king's position. This is the first prominent image of the prominent Taq-e-Bostan, which is located next to the small arch. On the right side of the little porch, there are stones that feature the crown taking by Ardeshir II, a Tajik scene, the ninth Sassanid king. In this scene, the Sassanid king is in a standing position with three pockets and body with full face, all at the center of the scene, placing his left hand on the sword and holding the right hand of the loop of the scroller from Ahura Mazda, in which the Zoroaster or the proverbial Mitra with a halo of light on the left is behind him. Under Ardeshir II, Julian is the Roman emperor who was captured in the war. The Sasanian King has big eyes and great eyebrows. His beard is curly and his hair is hanged massively on his shoulders. He has earrings on the ears and a necklace in his neck and bracelets on his wrist. His earrings are in the form of a circular ring that hangs a small ball. His necklace also includes a row of large pearl necklace. (razi,1366,246). 


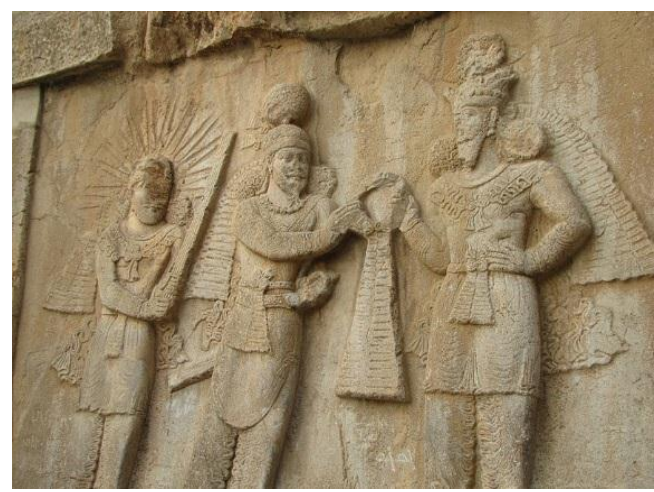

Figure 3. Embellished by Side of Small Tag while Ardeshir Crowned Accompanied by Ahura Mazda and Zardosht, Wikipedia

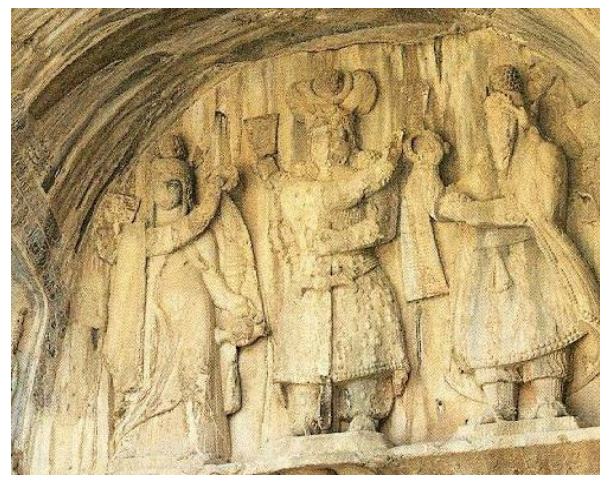

Figure 4. The Prominent Crown prince of Khosrow Parviz with Foruhar and Anahita,

Wikipedia

Also in the image of Rostam is depicting the scene of Deyhim's award, glory of God, by Ardeshir Babakan. In this image, Ardeshir Babakan is on the left of the parliament, riding a horse and engaging in horse riding in front of him Ahura Mazda, who has been drawn from the profile. To emphasize the greatness of Ahura Mazda and Ardeshir, the size of the horses was much smaller than normal'(pour bahman,1386,175). Ahura Mazda extends his right hand to Ardeshir and donates to the king a deyhim or a ring of flowers and hanging strips"(nafisi,1384,2523) In the Iranian iconography, Deyhim is a symbol of glory or the success of the divine and heavenly God given to the king and his family"(yarshater,1389,1081). Ahura Mazda in his left hand holds branches or canes that may be the reins of the monarchy."(nafisi,1384,252).

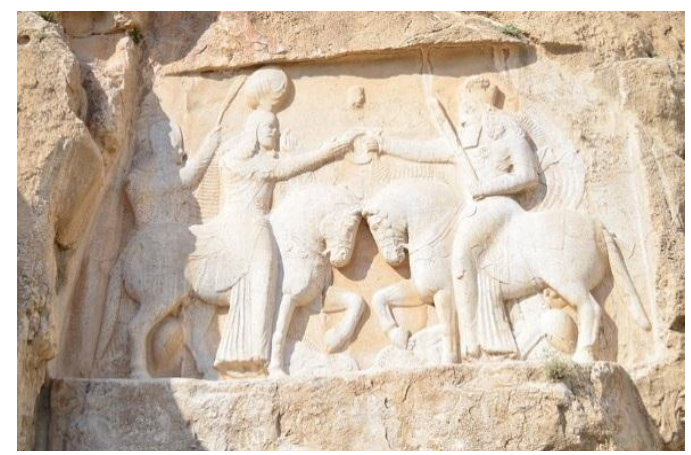

Figure 5. A prominent Image of Rustam, Ahura Mazda, and Ardeshir Babakan, Wikipedia 


\subsection{Plates with Hunting Images}

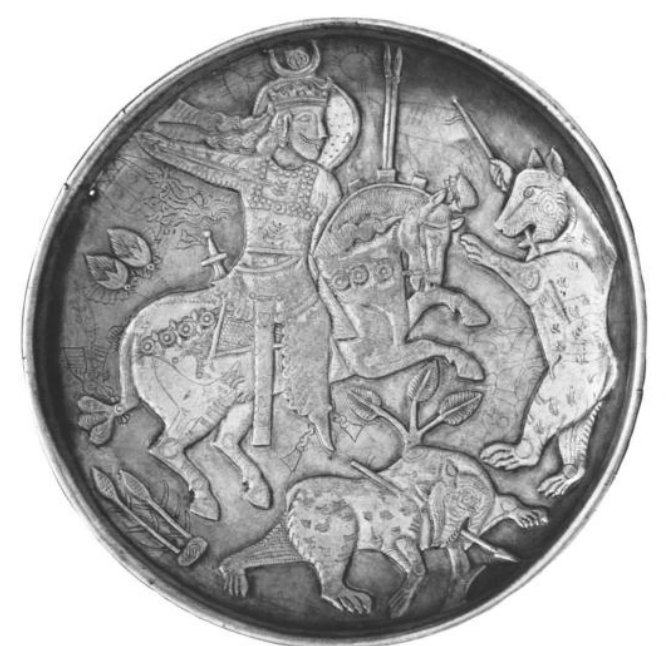

Figure 6. Silver Plate, King Bear Hunting, Pushkin Museum, Harper Page 222

In this plate, the king hunts a bear while riding a horse. The rider is moving from left to right. The face of the king is in profile while the upper body is facing the picture. There is also a halo around the head of the king that is a sign of divinity and holiness. The king has a beard and mustache and curly hair, and from the back there are two hanging wavy strips. The horse also has treadmills, especially in the saddle. Its tail is knitted and there are also two cone tweaks from the back of the saddle hanging is shown in all the scenes. There are two bears in the scene where one is fighting and the king is pointing the spear towards him and the other is falling. It is worthy of note that, in a particular way, the Sasanian art was the same as one bear that was embodied twice, first jumped into the King, and in the next moment, the Shah's spear made it to fall down to his feet. In Figure 7, the tree is also visible which resembles the forest.

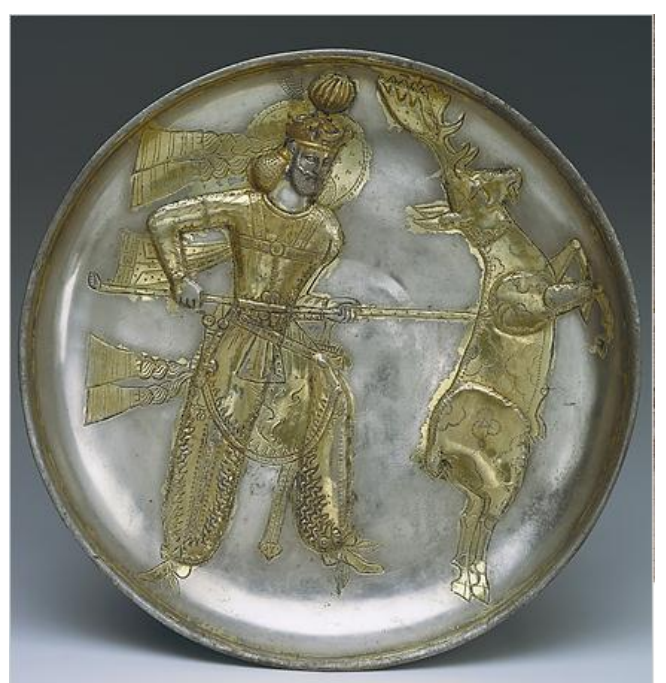

Figure 7. First Yazdgerd is Hunting Deer, Late $4^{\text {th }}$ Century and Early $5^{\text {th }}$ Century, the Metropolitan Museum, 22.3 Centimeters in Diameter (www.metmuseum.org) 
On this plate, Yazdgerd I (399-420 AD) is walking, but in hunted dress with a dart is hunting a deer. The shah is in the center of the plate and is larger than the deer; the crown of the shah is also congregated with a ball and a halo behind the shah. Long stripes are hung from the back and down the shirt of the king. Empty background and only king and deer are carved. Deer body is also designed. The background is silver and the bodies are gold-plated.

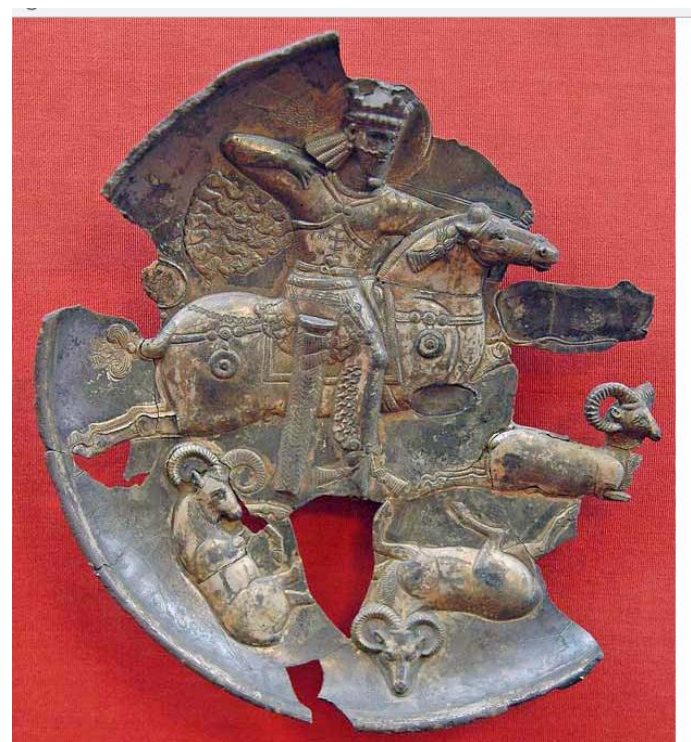

Figure 8. Golden Hunting Plate of Shapur II, $4^{\text {th }}$ Century, Diameter $23 \mathrm{~cm}$, Hermitage Museum (www.hermitagmuseum.org)

On this plate, Shapur II (309-379 AD) is riding a horse while throwing arrows with bow to a number of rams. Parts of the plate are gone and the King has a congressional head. But if there are other decorations, they are gone, the king's head also has a halo. The horse is decorated with tassels and saddles. Two rams have fallen on the ground and the other ram is running away. The face of king is shown in profile and the upper body is facing the picture.

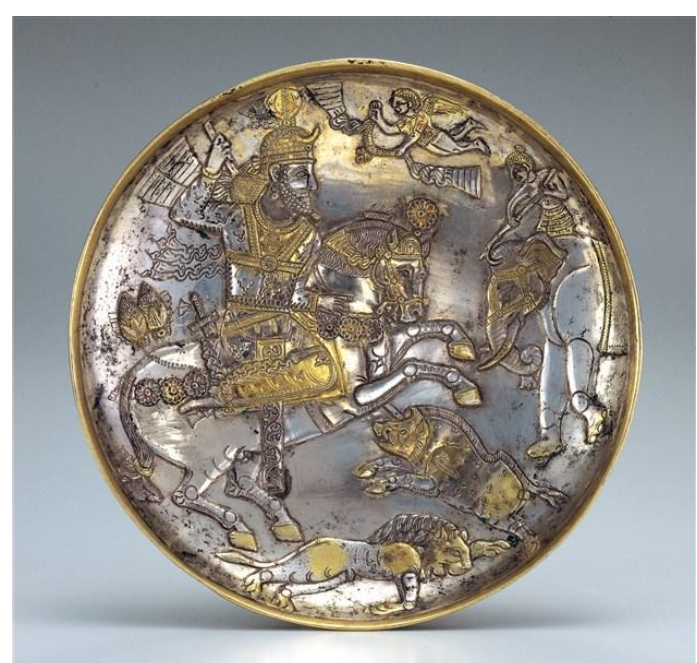

Figure 9. Golden Plate, $1^{\text {st }}$ Ghobad Hunting, $6^{\text {th }}$ Century, Miho Museum, Qazar $20 \mathrm{~cm}$. (www.miho.org) 
On the top plate, the first Ghobad (488-496 AD) is hunting while on horseback. He has a simple crown with a crescent moon on top of it over the head. The hair and beard are long and woven and the strips hang like the previous ones. The king also has earing. The horse is decorated. In another scene, the hog attacked the horse and the lion has fallen under the shadow of the kingdom, the king pulls his sword out of the pod. On the right, elephant and elephant keeper are pushing away the animals, and this is the only hunting scene in the plate in which the elephant is depicted. At the top of the king, the angel will bring a winged kingdom of Deyhim or a royal symbol to the king.

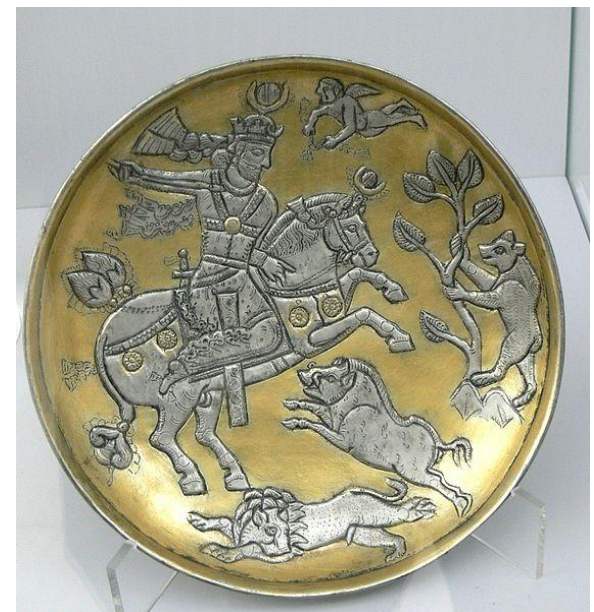

Figure 10. Golden Plate; Bahram Gur Hunting, 7th Century, Berlin Museum, Diameter 19 cm (www.smb.museum)

On this plate, Bahram Gur (421-438) is hunting on horseback with a coronal crown with a crescent moon and a hollo on top of it. The king has beards and long hair and hanging ribbons behind the head. Hunting is in the mountains and the tree and a few hills indicate it. The lion has fallen on the ground and the ram is attacking the king and the king moves towards him with a sword. A wolf is standing behind the tree and watching. On top of the figure, a winged angel is flying toward the king with a deyhim in its hand. The horse is decorated as before, with the exception that there is a crown on top of the horse head with a crescent which shows the importance of the horse to the king.

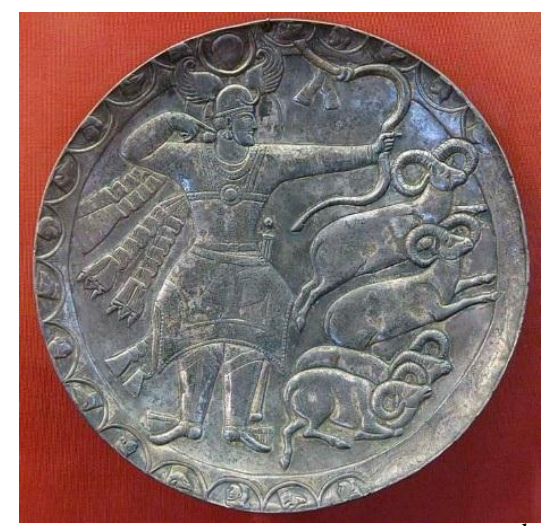

Figure 11. Golden Plate, Victorious King Hunting Rams, $6^{\text {th }}$ Century, Hermitage Museum, Diameter of $24.6 \mathrm{~cm}$. (www.hermitagmuseum.org) 
The shah, who is probably victorious (457-483 AD), is walking at the center of the plate and throwing arrows towards the rams. The King has a congregational crown with crescent of moon in front and two raised wings are on the sides of the crown, which is the symbol of Bahram god. The king is decorated with beards and woven hair and earrings, and stripes on the back of her garment. Round the king's head, the halo of light carved out with wings raised the goddess of the king. A wavy strip is also visible on the bow. The only sample of the plate which is decorated all around it with hog and king head is shown. The head of hog is a symbol of power and strength, as well as the manifestation of the goddess of Bahram, as described above. The head of hog is probably designed for the forehead of king and shows victory. In the picture, two rams have fallen on the ground and two other rams are running out. According to the Sassanian tradition, these two ram hunted are the same two rams before the hunt.

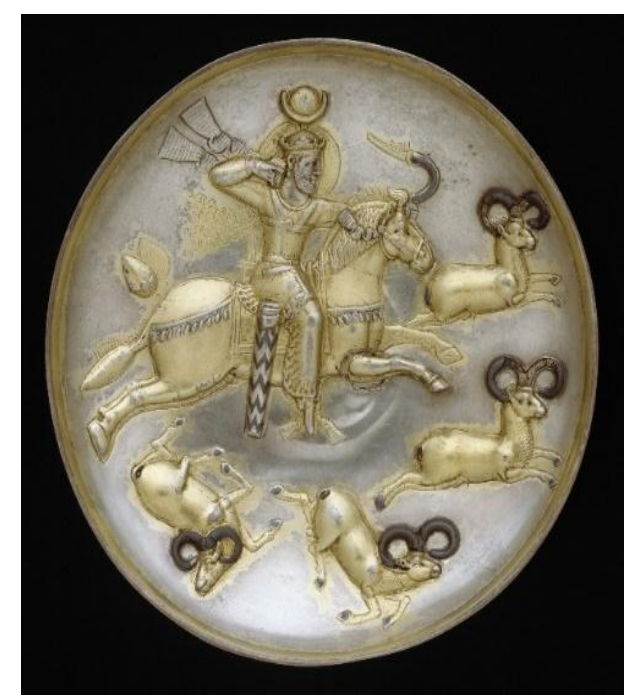

Figure 12. Golden Plate, Khosrow Parviz King is Hunting Hog, $5^{\text {th }} \& 6^{\text {th }}$ Century, Metropolitan Museum, Diameter of $22 \mathrm{~cm}$. (www.metmuseum.org)

In above picture, the king is riding a horse in the center of the plate with a bow drawn to rams. The king is seen with a congressional crown and a round large crescent of the moon in the middle of it. The halo is carved around the head of the king, and the face of the king is displayed in profile with beard and woven hair, and the hanging ribbons are hung from the back of the horse and the king. The horse also has a tent and saddle with decorations. The arc also has a wavy strip. Two rams on the bottom of the plate and two other rams are escaping. The bodies are all golden and with the silver background. The horns of the rams are also black. 


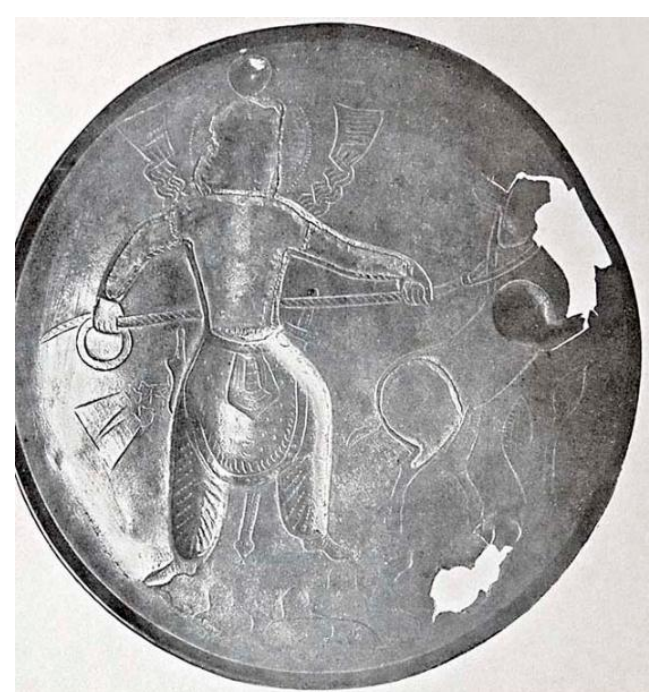

Figure 13. Golden Plate, $3^{\text {rd }}$ Shapur is Catching a Zebra, $4^{\text {th }}$ Century, Armitage Museum, Diameter of $22.5 \mathrm{~cm}$. (www.hermitagmuseum.org)

In above picture, Shapur III (383-388) is a pedestrian and catching a zebra with rope which is called kamand. A hunt which has not been seen yet. The crown of the king is gone, and only the circle on top of it and the round halo are clear. On the shoulders of the king, there are two wavy strips in the wig and stripes in the bottom of the dress. The tree and the stone are seen at the bottom of the scene. The king has held the rope with both hands and pulling the zebra toward himself. The sword of the king is on his waste. In the beliefs of Iranians, the zebra hunt brings a chance. But the king is undoubtedly trying to tame the zebra because he has taken him with a rope.

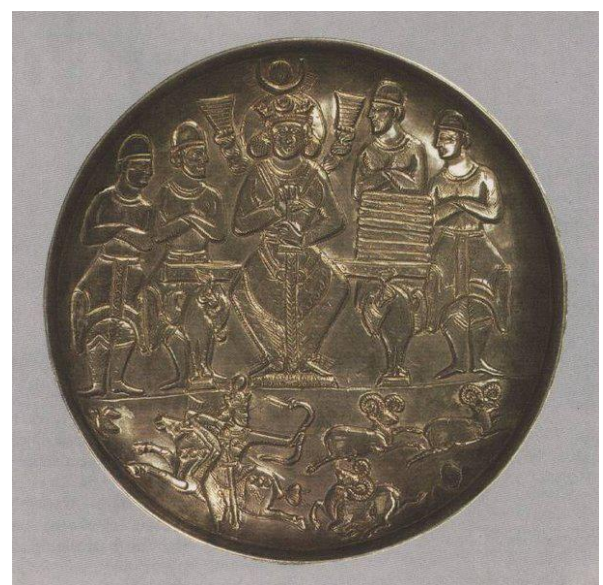

Figure 14. Golden Plate, $2^{\text {nd }}$ Shapur is Seated on the Throne, $6^{\text {th }}$ Century, Armitage Museum, Diameter of $26 \mathrm{~cm}$. (www.hermitagmuseum.org)

This is the only plate in which two images depict the king, one sitting alone on the bed with the courtiers, and below the scene of the same king is hunting. And this change occurs at the end of the Sassanid era, which is to take place at a scene of Shah's sitting and hunting. Shah with a coronal crown and a crescent of the moon and a round halo and a sword in hand on a bed with its bases of two winged animals and his courtiers standing on its sides. In the hunting scene, the king is riding a horse from the right to the left and is throwing arrow from left to right. A ram is on the ground and two others are escaping. In the left side of the 
scene, a bird is flying and this is the first time a bird is drawn which reflects the place being a hunting area. The place below the ram also shows the hill and the tree.

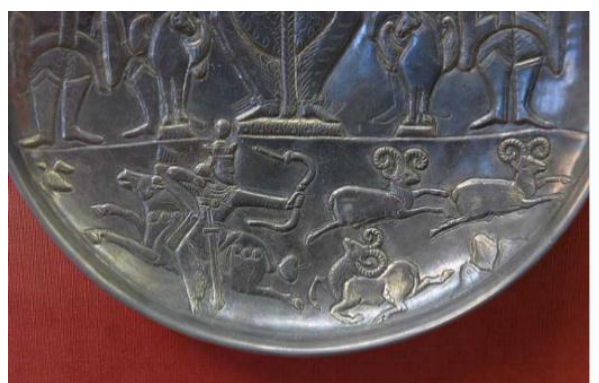

Figure 15. Khosrow Parviz Hunting Scene (www.hermitagmuseum.org)

\section{Conclusion}

Considering the design and role of the Sassanid Silver plates and the particular attention given to their details, it can be seen that these vessels were produced under the supervision of the Shah and in royal workshops. In these plates, the king's body is completely and detailed in such a way that it can be determined that this person is which one of the Sassanid kings. This is evident in his coverage and the means that comes with it. One of the most important signs is the royal crowns and their various decorations.

In all scenes, the king is larger than the rest and in the middle of the plate, and except for the shah, no one else is hunting, which indicates that the hunt was dedicated for the king. It should be noted that during the Sassanid period, religion and Zoroastrian religion were directly linked to reign, and the kings of this period, in order to legitimize their monarchy, always had the kings try to show this relationship with divisors and super universes, in order to show the people that they are of the descent of the goddess. Meanwhile, in the scenes of hunting, in the containers of Silver, in the prominent or in the coronation, depicted signs such as Farah Yazidi and the halo of sanctity and the presence of angels.

The scenes of hunting showed the king's victory over the forces of evil and enemies, and with the symbolic interpretation of the hunted animals, the spectator would follow the power and divine power of the Shah. And since these plates were sent across the country and even beyond the boundaries, the glory and majesty of the king in these plates was clear to everyone. For all this elegance is to show the appearance of the king and even his horse to show the king's position.

\section{References}

Amoozgar,Jaleh, (1387), Tongue, culture, myth, published by: Moeen.

Akhavan aghdam, Neda, (1393), iconography interpretatation of the scense of the hunting in the metal dishes of Sassanid era, kimiay-e- honar.

Bayani, Banoo Malek zadeh, (1351), Hawk, symbol of Yazadi's Far, historical surveys, 7th year.

Cirlot, juan Eduardo, (1388), A dictionary of symbol, translated by: mehrangiz ohedi, Tehran.

Christensen, Arthur, (1370), Iran in the age of Sassanid era, translated by:rashid yasemi published by donya ketab.

Dadvar, Abolghasem \& Khosravifar, Shahla, (1390), comparative study of the role of hunting in art of ancient Persia with Mesopotamia art, scientific journal of motaleate-e tatbighie Honar. 
Dadvar, abolghasem \& mansouri,elham, (2006), an introduction to the myths and symbols of Iran and India in the ancient, kalhor publishing, Tehran.

Ettinghausen, Richard \& Yarshater, Ehsan, (1379) highlights of Persian art, published by agah, Tehran.

Ferrier, r.w, (1995), the art of Persia, published by yale university, Tehran.

Georgina, Hermann, (1373), The revival of art and civilization in ancient Iran, translated by : mehrdada vahdati, published by nashr daneshgahi. tehran

Hall, james, (1380), illustrated dictionary of symbolism eastern and western art translated by: roghie behzadi, published by farhang-e- moaser.

Hinnells, john russelle, (1373), "Persian mythology", translated by jale amozegar,published by cheshmeh.

Ganther, Paul Jet,(1383),Iranian metalwork during the Achaemenid, Parthian and Sassanian periods, translated by: Shahram heydarabadiyan, published by: Ganjineh honar, Tehran.

Mohebbi, Hamidreza, (1384), Signs in the big arches in Tagh-e-Bostan, Honarhaye Ziba, NO: 23.

Mobini, mahtab \& zadsar, Zahra, (1396), study the role of tin in sassanid plates, pazhoheshe- honar.

Mousavi haji,seyyed rasul, (1373), An Analysis of the Identity of Plaster Plates Huntsman of the Chal Torkhan-Ashgabat journal archeology, university of Tehran,volum7,No:1, spring \& summer.

Muhammad, Sukiman, Irwansyah. (2019). Social Status Shift and Collapse of Uleebalang in Aceh of 1900-1946 Budapest International Research and Critics Institute-Journal (BIRCI-Journal) Volume 2, No 2, May 2019, Page: 36-47

www.bircu-journal.com/index.php/birci

Nafisi, Saeed,( 1384), History of Sassanian Iran Civilization ,published by: asatir, Tehran.

18.Poorbahman, Fereydoon, (1386), Clothes in ancient Iran , translated by: Hajar ziya sicaroodi, Amir kabir publishing house, Tehran.

19. Pane.I . Suwantoro.H. (2019).The Study of Indisch Architecture Development as an Effort in Preserving the Heritage of Colonial History in Medan. Budapest International Research and Critics Institute-Journal (BIRCI-Journal) Volume 2, No 4, November 2019, Page: 207-214 www.bircu-journal.com/index.php/birci

Pope, Arthur, (1378), masterpices of iran , translated by: khanlari, parviz, published by elmi farhangi.

Porada, Edith ,(1358) The Art of Ancient Iran, published by Tehran university,1353

Rajabi, Parviz, (1387), Iranian celebrations, published by: Artamis, Tehran.

Razi, Hashem, (1366), History of Iranian studies, published by: faravahar.

Riyazi, Mohammadreza, (1383), Sassanid era designs and motifes, Neshan, NO: $4 \& 5$.

Shahbazi, Alireza, (1357), Illustrated description of Naghshe Rostam, the Achaemenid astronomy foundation, Tehran.

Schippmann, Klaus, (1383), Sassanian imperial history, translated by: Faramarz najd samiee, published by: Country heritage organization.

Tajbakhsh, Ahmad, (1353) Brief History of Iranian Civilization and Culture, National University Press.

Vosogh Babae, Elham \& Mehrafarin, Reza, (2015), Iconography of the scenes of hunting in the Sassanid Era", scientific journal of negareh.

Yarshater, Ehsan, The history of Iran, translated by: Anoosheh, Hasan, $5^{\text {th }}$ publishe, published by Amir kabir, Tehran. 